\title{
What should be taught in courses on social ethics?
}

\author{
Alan Tapper
}

alandtapper@gmail.com

\section{Abstract}

The purpose of this article is to discuss the concept and the content of courses on "social ethics". I will present a dilemma that arises in the design of such courses. On the one hand, they may present versions of "applied ethics"; that is, courses in which moral theories are applied to moral and social problems. On the other hand, they may present generalised forms of "occupational ethics", usually professional ethics, with some business ethics added to expand the range of the course. Is there, then, not some middle ground that is distinctively designated by the term "social ethics"? I will argue that there is such a ground. I will describe that ground as the ethics of "social practices". I will then illustrate how this approach to the teaching of ethics may be carried out in five domains of social practice: professional ethics, commercial ethics, corporate ethics, governmental ethics, and ethics in the voluntary sector. My aim is to show that "social ethics" courses can have a clear rationale and systematic content.

\section{Keywords}

Moral theory; social ethics; professional ethics; commercial ethics; corporate ethics; public sector ethics; voluntary sector ethics

\section{The concept of "social ethics"}

Cicero, writing to his son Marcus in 44BCE, observed that (On Duties, Book 2, sections 39-40; 1913, pp. 208-209) "every walk and vocation in life calls for human co-operation - first and 
above all, in order that one may have friends with whom to enjoy social intercourse. And this is not easy, unless one is looked upon as a good man". In addition,

So also to buyers and sellers, to employers and employed, and to those who are engaged in commercial dealings generally, justice is indispensable for the conduct of business. Its importance is so great, that not even those who live by wickedness and crime can get on without some small element of justice. For if a robber takes anything by force or by fraud from another member of the gang, he loses his standing even in a band of robbers.

If a sense of justice is important to robbers, he asks, how much more important must it be to more ethical citizens? "Since, therefore, the efficacy of justice is so great that it strengthens and augments the power even of robbers, how great do we think its power will be in a constitutional government with its laws and courts?"

More controversially, Cicero holds that morality is a subject that can be taught and that needs to be learned. His own On Duties became a central text in the Western university curriculum through to the twentieth century; as Sidgwick (1919, p. 95) observed, "there is probably no ancient treatise that has done more than his De Officiis [On Duties] to communicate a knowledge of ancient morality to medieval and modern Europe". It was admired by Augustine, Aquinas, Petrarch, Erasmus, Melanchthon, Grotius, Bayle, Voltaire, Locke, Hume, Smith, and Kant. Following in the tradition of Cicero, university and college courses on ethics were once held in high esteem in the academy and the community. Douglas Sloan (1980, p. 2) conveys this well:

Throughout most of the 19th century the most important course in the college curriculum [in America] was moral philosophy, taught usually by the college president and required of all senior students. The moral philosophy course was regarded as the capstone of the curriculum. It aimed to pull together, to integrate, and to give meaning and purpose to the student's entire college experience and course of study. In so doing it even more importantly sought to equip the graduating seniors with an ethical sensitivity and insight needed in order to put their newly acquired knowledge to use in ways that would benefit not only themselves and their own personal advancement, but the larger society as well. 
Today, in our very different social world, university courses on ethics come in roughly three types. One is occupational ethics, such as business ethics, healthcare ethics, or various forms of professional ethics. These courses are designed for students taking the relevant vocational degrees. The second is philosophical ethics, courses designed for philosophy students, inquiring into the foundations of ethics and meta-ethics. The third is what I will call "social ethics".

The concept of "social ethics" covers all those courses that are neither narrowly occupational ethics nor abstractly philosophical ethics. Such courses are designed to serve students with a general interest in ethics and who want to learn to think constructively about ethical issues and problems. In describing "social ethics" in this way, it suggests I am speaking of it as a residual category - it is that which is left over after subtracting the other two types of course. But this tells us nothing about the positive content one would expect to find in such a course. I will try to find a content, proceeding both inductively and conceptually.

But first: who, in academic terms, owns and teaches "social ethics"? This question has a clear answer: the subject belongs to philosophy and is taught by philosophers, often as an elective course offered to the university in general. It is usually a "service course", similar in that respect to courses in critical thinking. In theory we could imagine non-philosophers offering such courses, but in practice that almost never happens. The explanation for this is, presumably, that social ethics involves a level of conceptual and theoretical content that non-philosophers don't pretend to command, and also because the subject has a normative aspect that makes empirically-focused academics uncomfortable. Thus, we can safely assume that social ethics is a discipline belonging within the domain of Philosophy. Occupational ethics may of course be different. The teaching in those fields will usually involve specialists in the occupational field, usually academics with no formal training in ethical theory, sometimes working with and sometimes without the assistance of philosophers. 
Secondly, we need to distinguish between social ethics and political philosophy. Whatever social ethics might be, since it deals with the ethical dimension of social problems, it will overlap to some degree with political philosophy. Sometimes courses combine the two under the heading of "social and political philosophy". Here I will treat the social and the political as distinct domains, and exclude discussion of the political domain.

In what follows I will focus on the textbook literature that might be used in courses on social ethics, with the aim of examining how they are grounded in the broader ethics literature.

\section{Social ethics as applied ethics}

What then might social ethics be? One approach to social ethics is to treat it as the application of moral theory or theories to social and interpersonal problems. This is commonly what is understood by the idea of "applied ethics". Usually the menu of theories is the standard trio of consequentialism (or utilitarianism), deontology (sometimes called "Kantian ethics" or "respect for persons"), and "virtue theory". Some add "natural law theory" and "egoism" (Harris, 2007). But the repertoire of theories can be much greater. The Wikipedia entry on "Ethics", for example, adds to the standard three: anarchist ethics; ethics of care; intuitive ethics; hedonism; pragmatic ethics; postmodern ethics; and role ethics. Peter Singer's 1991 compilation, A Companion to Ethics, offers chapters by distinguished philosophers on ten kinds of ethical theory: natural law; Kantian ethics; the social contract tradition; egoism; contemporary deontology; an ethic of prima facie duties; consequentialism; utility and the good; virtue theory; and rights. In the philosophers' professional website PhilPapers, "normative ethics" is said to lie between "meta-ethics" and "applied ethics" (See https://philpapers.org/browse/normative-ethics). It is said that "Many philosophers in normative ethics investigate ethical theories the aim of which is to systematically describe what makes acts right and wrong. These theories include utilitarianism, consequentialism, Kantian theories, contractualism, contractarianism, virtue ethics, various pluralist views, natural law theory, and so on." If there are eight or ten or some other large number of "theories" about some matter, can it really be said that any of these are theories? 
Underpinning "moral theory", often though not always, is the ambition to give an account of ordinary morality from outside morality, an account that makes no moral assumptions and employs no moral concepts. Morality is to be grounded in "consequences", measured in terms of "happiness" or "utility", or in rationality, the avoidance of contradictions and inconsistencies, or in rational self-interest, or in divine commands, or whatever else. The ambition assumes that morality is not self-explanatory or self-justifying. Of course, the theories have to account for actual everyday morality if they are to claim any explanatory success, so they do not entirely replace morality as it is actually lived. It is very much a philosopher's problem. The question here is whether there is any value in allowing this ambition to shape courses not designed primarily for philosophy students.

The repertoire of social problems to which ethical theories can be applied is very large and changing over time. From the inception of "applied ethics" in the 1970s, the early textbooks focused on abortion, euthanasia, capital punishment, the treatment of animals, environmentalism and warfare. Singer's book adds to these, chapters on: world poverty; sex; personal relationships; equality, discrimination and preferential treatment; business ethics; crime and punishment; and politics and the problem of dirty hands. Wikipedia offers nine types of "applied ethics": bioethics; business ethics; machine ethics; military ethics; political ethics; public sector ethics; publication ethics; relational ethics; and animal ethics. In PhilPapers, "applied ethics" is subdivided into: biomedical ethics; business ethics; environmental ethics; philosophy of gender, race and sexuality; professional ethics; political ethics; social ethics; and technology ethics. The category here called "social ethics" is a rather miscellaneous one, embracing "deception", "disability", "family ethics", "friendship", "philosophy of sexual orientation", "philosophy of sexuality", and "sports". (See PhilPapers, Applied ethics.) While all these topics might be part of a course in social ethics, this is not exactly what is meant in courses called "social ethics". Clearly, the taxonomy of ethics is not an exact science!

The problem for anyone designing a course on social ethics, conceived as a kind of applied ethics, can be simply stated: there are too many theories and too many topics to which the theories may be applied. The selection of topics may not be an insuperable difficulty; it can be solved by simply choosing a selection from the very large range, or by allowing students 
to investigate a topic of their own choosing. The selection of theories is more troubling. How many of these theories do we expect students to understand? If we agree that ten is too many and we narrow the selection, why those theories and not others? How should the teacher's own theoretical stance enter into this? Even more troubling: how exactly is any theory to be applied? "Cookie-cutter" application (as we now call it) is the implicit model at work here: take a lump of social "dough" and cut the dough into shape with the cookie cutter theory. This is not how philosophy is properly done, it is not morally illuminating, and it cannot give students a good impression of the value of philosophy. This criticism is well expressed by Buchholz and Rosenthal (1999, p. 312):

this approach is that we are left with a kind of ethical smorgasbord where one has various theories from which to choose that will hopefully shed some light on the ethical problems under consideration and lead to a justifiable decision. However, we are never told to any extent exactly how we are to decide which theory to apply in a given situation, what guidelines we are to use in applying these different theories, what criteria determine which theory is best for a given problem, and what to do if the application of different theories results in totally different courses of action.

One might go in the opposite direction and try to "do" applied ethics by dropping out the "theory" component. Brenda Almond's edited collection, Introducing Applied Ethics, starts out with a short chapter by Almond called "Introduction: Ethical Theory and Ethical Practice" (1995, pp. 1-14). The effect is to suggest an anti- or at least non-theoretical ethical stance. There is a similar approach in A Companion to Applied Ethics, edited by R. G. Frey and C. H. Wellman (2003), which consists of fifty chapters on controversial social topics but only two chapters (37 pages) on ethical theory. But, since the quest for general explanations and justifications seems to be intrinsic to philosophy, the question is, again, where's the philosophy in this approach? Are students supposed to conclude that each ethical problem is sui generis? 
While the dominant understanding of social ethics is the applied ethics model, there is a rival approach to the subject for which we have no suitable general term, and calling it "generalised occupational ethics" is not very helpful. I have in mind the model at work in two textbooks: Ethical Issues in Professional Life, edited by Joan C. Callahan (1988), and Ethics Across the Professions, edited by Martin, Vaught and Solomon (2010). These books take "professional ethics" as central. It is a defensible decision, given that most university students will graduate to become members of some profession. The books serve to prepare students for the ethical challenges they may encounter in their professional careers.

Neither book attempts to introduce their readers to the complex issues raised by "moral theory". Rather, they offer philosophical wisdom to help students with workplace challenges. Because, arguably, professional ethics rests on widespread agreement about the nature of professions and their role in society, the content of this type of ethics is not open to the sort of unending disputes characteristic of moral theory. Disagreement in this field is constrained disagreement. (For a summary account of professional ethics, see Tapper \& Millett, 2015.)

Nevertheless, the idea of social ethics as an expansion of professional ethics suffers from some important limitations. One is that many students who might take a course in social ethics are not majoring in professional disciplines. This is true of many business students and also many arts and humanities students. While it is useful for them to learn about professional ethics, what else should they be learning that would be equally useful? Business ethics is one subject area that will be important for them. An understanding of business ethics is also valuable for students from the professional fields. And why not also government ethics? Many graduates will work in public administration in one form or another. Taken together, this suggests that the ideal course in social ethics would strike a balance between the teaching of professional, business, and government ethics.

A recognition that a focus on professional ethics is too narrow for the purpose is implicit in the two textbooks. Ethical Issues in Professional Life includes a section on "Individual and Collective Responsibility" which covers issues in corporate ethics, a section on "Social Responsibility and Professional Dissent" which covers issues of whistle-blowing, and a 
section on "Social Responsibility and Justice" which covers issues of business ethics and social justice. Similarly, Ethics Across the Professions includes a section on "Integrity and Loyalty: Whistle-Blowing and Self-Regulation" which covers whistle-blowing and organisational loyalty, and a section on "Professionalism, Justice and Social Welfare" which covers issues of social justice. Clearly, these textbooks go well beyond just the professional domain. But they contain nothing on government ethics. We could imagine a different balance being struck in which professions, business, governance and social justice are equally represented. This wider approach would make "occupational ethics" the central idea.

To go in this direction is to ground social ethics largely in the world of work. This has the advantage of building ethics upwards from the accepted moral principles and practices of the working world, which is surely part of what soon-to-graduate students need to know. But what then of moral theory? Ethics Across the Professions begins with a chapter - just 23 pages in a book over 400 pages long - on "Basics and Background". Ethics Across the Professions deals with moral theory in its second chapter, entitled "How to Be Ethical", just 43 pages in a book also over 400 pages long. These are not foundational chapters and nothing much is presented as following from them. Both books adopt an approach that minimalises moral theory.

A similar issue arises in the textbooks on business ethics. What is the right balance between theory and application? The Blackwell Guide to Business Ethics (Bowie, 2002) is all application and no theory. Many moral philosophers, deeply invested in moral theory, will likely consider this approach indefensible. But another Blackwell product, A Companion to Business Ethics (Frederick, 1999) allocates eleven chapters (138 pages) to "normative theories", with no attempt to integrate these "theories". It is hard to see how this will not cause confusion to newcomers. We need something better.

\section{Social ethics as the ethics of social practices}

The position I am proposing is one that combines the ethics of business, professions and government. By "government" here I mean the ethics of working in and for government, not 
the ethics of politics or political philosophy. On my account so far, it is a neglected field of ethics, by comparison with the familiar topics of professional and business ethics. It needs some explaining. It includes not just the activities of government departments, but also those of the police, the military, the judiciary, integrity commissions, regulatory agencies, and planning authorities.

A second preliminary point in my approach is to distinguish between the ethics of commerce and the ethics of corporations. Not all corporations are businesses (hospitals, universities, religious organisations, sporting clubs, charitable foundations, for example); not all businesses are corporations (sole traders, partnerships, family businesses, for example). It is an obvious distinction, but one that is often overlooked, usually by being blurred by loose use of the idea of "business" in the concept of "business ethics". The point is important because, in my view, the ethics of commerce is distinct from the ethics of corporations, and students need to have that distinction clearly spelled out.

A third preliminary point is that this "world of work" approach, if interpreted narrowly, leaves out another field of activity: the world of voluntary associations, which also has a distinctive ethic. Putting the point more broadly, students should be introduced to the dimension known as "civil society". It is a familiar and plausible thesis that healthy modern societies are healthy to the extent that they are rich in the voluntary associational activities that we call "civil society".

Thus, I am suggesting that courses in "social ethics" should introduce students to five domains and the ethics that go with each: professions, commerce, corporations, government, and civil society. These should each be conceived as forms of social practice. The concept of a social practice stretches wider than these five, and includes the social practices of private life, such as marriage, family, parenthood, and friendship, which may be seen as forming a sixth domain and which may or may not be included under the umbrella of "social ethics". But distinguishing between these five (or perhaps six) domains would be rather pointless were it not that I am proposing that each has a distinctive ethic. To make my argument for "social ethics" I need to defend the distinctiveness claim. I will sketch such a defence later in this essay. 
The argument so far will likely bring to mind similar views argued by Alasdair Maclntyre, most notably in After Virtue. Maclntyre has made the concept of a "social practice" central to his moral philosophy. He defined the concept as:

any coherent and complex form of socially established cooperative human activity through which goods internal to that form of activity are realized in the course of trying to achieve those standards of excellence which are appropriate to, and partially definitive of, that form of activity, with the result that human powers to achieve excellence, and human conceptions of the ends and goods involved, are systematically extended. $(1985$, p. 187)

He observes that "the range of practices is wide: arts, sciences, games, politics in the Aristotelian sense, the making and sustaining of family life, all fall under the concept" (Maclntyre, 1985, p. 188). As illustrations of his version of the concept he tended to give examples of professions (architecture, medicine), voluntary associations (soccer clubs, chess clubs, churches, string quartets, trade unions) and small communities (university colleges, fishing villages). As illustrations of what in his view is not a social practice, he mentions management, teaching, psychotherapy and brick-laying - that is, a corporate role, two professions, and a skill or perhaps a trade.

My line of argument about social ethics also resembles Maclntyre's "meta-ethical" position, summed up by the contention that "Moral concepts are embodied in and are partly constitutive of forms of social life" (Maclntyre, 1967, p. 1; for further development of this idea, see Harrison, 2012, Ewin, 1981, 2012; Kovesi, 1967, 2004). If we accept this thesis, we will see it as natural that ethics has to be taught in relation to social practices. But MacIntyre's choice of illustrative examples casts doubt on whether the activities of modern government, commerce and corporations can be counted as kinds of social practice.

The question has led to a productive debate amongst "Maclntyrean" philosophers. Some, like Beadle $(2008,2002)$, argue that Maclntyre has shown that much of modern "capitalism" is antipathetic to the ethics of social practices. Others, such as Moore (2002), try to show Maclntyre's account of virtues can be applied to business and corporate life. Beadle and 
Moore have summarised Maclntyre's own position (Beadle \& Moore, 2006). Moore has elaborated his position in his Virtue at Work (2017). On a different front, Maclntyre and Dunne (2002) have expanded the argument that teaching is not a social practice, while Noddings (2003) has defended the idea that it is a form of social practice, with its own internal standards of excellence. Hager (2011) has refined the account of practices in the debate about education.

Maclntyre's account of social practices has led to fruitful questions about the relation between virtues and practices in modern societies. I am not entering into these questions here, but mention it simply to show one form that "social ethics as the ethics of social practices" can take and has taken. Less obviously, there are other forms it may take, if one adopts other accounts of the nature of a social practice. I will mention two authors who have offered such accounts: R. E. Ewin and Seamus Miller.

In Ewin's account (1981, pp. 51-70), a moral practice is a form of social cooperation - a sharing of benefits and burdens in a joint enterprise - in which the participating parties can make justifiable claims against each other. "[C]o-operation involves taking on a role or job as part of a larger job which others help to perform, the point of all these smaller, particular jobs being a contribution to some good.... [T] he fact that each can make claims (that others should do their jobs) and that each is liable to claims (that he should do his own job) is at the core of co-operation and marks it off from cases of exploitation and coercion" (Ewin, 1981, p. 61).

Claims are moral claims because they are couched in the language of justice. Indeed, the language of justice is itself a form of cooperation. "[S]ocial life is dependent on our cooperating with respect to basic decision-procedures for adjudication of disputes and allocation of claims and sacrifices. The most basic of those decision-procedures ... is our operation of the concept of justice" (Ewin, 1981, p. 64). Ewin has developed his version of the theory of social practices into a way of approaching issues in business and corporate ethics (Ewin, 1995; 1993; 1991). 
Miller (2009) talks of social institutions, not social practices. In his account, the central idea is that of a social institution serving the purpose of realising collective goods. He starts from a sociological standpoint. "Typically, contemporary sociologists use the term [social institution] to refer to complex social forms that reproduce themselves, such as governments, the family, human languages, universities, hospitals, business corporations, and legal systems" (Miller, 2009, p. 12). Ethics arises as a necessity within these institutions, but basic moral rights precede the institutions and provide part of the purpose or telos of the institutions. (Here he differs from Maclntyre, for whom "moral rights" have no foundational role.) From this background, he proceeds to give analyses of how ethics works in a variety of cases. The most notable of his analyses, for the purposes of this article, concern the professions, business corporations, and governments.

MacIntyre, Ewin, Miller, and Moore are here taken as exemplars of "social ethics as the ethics of social practices". No doubt other thinkers could have been drawn upon. The core idea is that social ethics emerges from forms of cooperation, which are diverse and serve diverse purposes. To understand ethics is not to learn mastery of a general theory applicable to any and all cultures and contexts, but to be proficient in a variety of actual social formations. The main point here is to show that this way of approaching ethics offers a plausible alternative to the moral theory approach and the occupational ethics approach. Of course, deeper questions can still be asked about the nature of cooperation, about the necessity of cooperation, and about how cooperation is related to justice, but I am taking these questions to be the province of courses on moral philosophy (and perhaps on metaethics), rather than courses on social ethics, courses which are addressed mainly to nonphilosophers.

I now proceed to discuss in turn five kinds of social practice - professions, commerce, corporations, government, and voluntary associations - which, I will argue, have distinctive ethical features. These distinctive ethical features are, or should be, core subject matter for courses in social ethics.

\section{Professional ethics}


I start with professional ethics. Two questions arise. (1) Is there something morally distinctive about professional ethics? (2) Can the key features of professional ethics be captured by the standard approach taken by "moral theory"?

On the first question, there is a widely-accepted view that professional ethics is morally distinctive. Speaking only of the medical profession, Rhodes (2001, pp. 494-95) sums up the social role of the professions as follows:

As I see it, roughly speaking, professions are defined (that is, constructed) by the set of knowledge, skills, powers, and privileges that a society entrusts the profession to have and to use for the good of its members. In a sense, society acknowledges that medical knowledge, skills, powers, and privileges are potentially very dangerous and that the activities of physicians require patients to make themselves vulnerable in very significant ways. Therefore, societies recognize that the knowledge, skills, powers and privileges of medicine should only be wielded by a special few. Hence we have a rather clear conception of the core characteristics that a doctor should personify (e.g., intelligent, able, responsible, honest, caring, respectful) and because we expect doctors, as a profession and as members of the profession, to be people of that sort, we allow them to exercise their special powers.

William May $(1975 ; 2001)$ crystallised that distinctiveness in the proposal that professional ethics is covenantal, not contractual. For May (2001, p. 710), a profession is "the art of acting in concert with others for the common good: (1) in the production of services; (2) in the distribution of services; and (3) in the quality control of services, through professional education, self-regulation, and discipline." A professional enters a covenant "that help distinguish professionals from careerists: the professional professes something (a body of knowledge and experience); on behalf of someone (or some institution); and in the setting of colleagues". "These distinguishing marks call for three correlative virtues - practical wisdom, fidelity, and public spiritedness." Professions typically have codes of ethics that to some degree specify what is required in practice by these virtues. 
The second question here is: can the key features of professional ethics be captured by the standard approach taken by "moral theory"? One way to answer this is to look at the moral theory textbooks. In Singer's A Companion to Ethics, which I take as representative of the moral theory approach, "professional ethics" is absent from the Index and from the contents. In a textbook introduction to practical ethics, this seems a remarkable oversight. If the textbooks give us no account of professional ethics, then at least the suspicion arises that they are not well suited to dealing with the issue.

Thus, there is a strong argument to suggest that professional ethics is morally distinctive, and from this it follows that if it is not taught explicitly it will not be "picked up" by extension from any of the standard moral theories. It needs to be taught explicitly if it is to be understood at all.

However, there is a counter-argument to be considered here. One of the most impressive and most influential contributions made by philosophers to modern moral thought is what is known as "principlism" in biomedical ethics. Principlism is the invention of a philosopher, Tom L. Beauchamp, and a theologian, James Childress (Beauchamp \& Childress, 2013). It proposes that problems in biomedical ethics can be best approached with four moral principles: respect for persons (or respect for personal autonomy); non-maleficence; beneficence; and justice. These four are derived from the wider world of moral theory. The first comes from deontology; the second and third are aspects of utilitarianism or consequentialism; and the fourth is, in the sense of "justice" at work here, Rawlsian. The field to which the principles are intended to apply is the moral deliberations of medical professionals - medicos, hospital managers, nurses, and healthcare providers. Since these are, for the most part, professional fields, the success of principlism (if it is successful) would yield an argument to show that moral theory can illuminate moral problems in at least one professional field. In theory, principlism could be extended to other professional fields, and thus could show that there is nothing distinctive about professional ethics.

There are, however, two basic difficulties with principlism. One is that it fails to explain when and why some one of the four principles is to take priority over the other three. Without such an explanation, principlism is not a theory of moral priorities but a set of 
options that can be exercised in whatever way seems intuitively persuasive. This difficulty has been much discussed. One proposed solution is to "specify" the general principles (see Gert, Culver \& Clouser, 2000; Richardson, 2000a; Richardson, 2000b; Strong, 2000). To specify a principle is to both narrow its extension, so that it applies only to a subset of possible cases, and to gloss its interpretation more fully, to show how it applies to that subset. In theory this may work, but it is not clear that anyone has shown it to work in practice.

The second is that professional ethics, as standardly understood, recognises an asymmetry between the professional and the client, and this asymmetry cannot be represented in the general moral principles that we see in principlism. The asymmetry is why professional ethics is commonly seen as covenantal and not simply as contractual. This argument is developed in Tapper and Millett (2014; see Lustig 2014 for a contrary view).

The alternative to the principlist approach is to start from professions as an established form of social practice and from there work towards clarifying the principles built into that practice. This is what Rhodes and May do. Miller $(2009,181)$ argues similarly, showing the economic consequences that follow: in the case of services provided by the professions, "The economic relationship of seller to buyer is secondary to the needs of the client and, more broadly, to the requirement to provide the collective good definitive of the particular profession in question".

Professional status is not self-created: it is the joint product of those with expertise and the wider society. How a profession gets accepted is a matter that needs explanation, especially when many occupations can be considered as "para-professional", and courses in social ethics need to at least sketch this issue. But the main point to be conveyed by social ethics courses is that professional ethics is one distinct kind of ethics, one that has certain unique features.

\section{Commercial ethics}


I have contended above that we should distinguish between "corporate ethics" and "commercial ethics", since corporations and commerce are distinct forms of social practice and each has distinctive ethical characteristics. Commerce is, to put it rather too crudely, just the practices associated with buying and selling. It forms a subset of the broad category of voluntary exchange, which takes many forms in human relations. Commerce is "transactional" rather than "relational". Its standard instrument is the voluntary contract. The parties to a contract may be natural or artificial persons. An act is voluntary if it is made by a competent agent and is not subject to force or fraud. The general ethical principle here is volenti non injuria fit - a contract freely entered causes no injury or wrong. Generally, the outcome of such a transaction will be of benefit to both parties, but if one party (or both) is worse off after the transaction has played out that is by itself no ground for ethical complaint. The obvious way in which ethical failure may occur is by breach of contract. Thus, to teach the ethics of commerce is, at the least, to teach the ethics of contract and of breach of contract. So far, so straightforward. Already, it should be obvious that this is an ethic very different from professional ethics.

On the face of it, then, commercial ethics fits very well with a moral theory approach to social ethics, particularly contractarian moral theory, or possibly with some form of deontology. On the other hand, commercial ethics presents a difficulty for consequentialist theories, since the consequences of otherwise ethical commercial transactions are commonly deemed to be irrelevant to the morality of the transaction.

A social practices approach to commercial ethics is also possible. It would start from the contention that contracts are a form of social practice. The words "I promise" contain no moral magic; they cannot by themselves make an act right or wrong. But the words, when uttered in the setting of the social practice of promising, do have moral force. The same applies to contracting. A contract, whether in a documentary form with signatures and witnesses or merely informal, involving just a nod or a handshake, is an artificial construct but one with objective moral force. Its effect is to change the rights of the parties.

But the ethics of commerce requires another, more challenging ethical concept: fraud. The test of whether moral theories can illuminate commercial ethics, I suggest, is whether they 
can explain the concept of fraud. If they can't explain that concept, they fall short of what is needed in the field of social ethics. Fraud matters not just in itself, but also because commercial reputation is tied to the idea of honesty in business. Reputation matters in business, and good reputation goes with honesty, and honesty involves transparency on one's dealings. Sharp practice, on the other hand, involves getting away with fraudulent-like behaviour.

The concept of fraud, as it might operate in commercial transactions, is surely a central topic in commercial ethics, and one to which students should be introduced. Traditionally, it has been assumed that professionals have a duty of disclosure that does not apply to parties in commercial transactions. The professional has an obligation to disclose any information that the client needs in order to give informed consent to some treatment or service. In commerce, the seller is not a professional in the strict sense of the word. The goods or services provided are not ones that rest immediately on forms of knowledge held by the seller. Hence, the buyer should beware. But is there no standard of honesty that applies in commerce? There is, presumably, an obligation to avoid fraudulence, whatever that might be. What then is it?

According to Wikipedia, "In law, fraud is intentional deception to secure unfair or unlawful gain, or to deprive a victim of a legal right". This just shifts the problem to explaining unfairness and legal rights. Strangely, the business ethics textbooks (likewise, Frey \& Wellman, 2003; Bowie, 2002; Frederick, 1999) are equally uninformative. What is needed, I suggest, is a philosophically-informed discussion of the concept. As I see it, the concept is both complex and central to commercial ethics, and is therefore a concept that needs to be explained philosophically to students of social ethics. Explaining the concept of fraud is one part of an account of good commercial practice, but good commercial practice has many other features at least some of which should be taught in courses on social ethics.

\section{Corporate ethics}

The general thesis of this article is that we should approach social ethics from an understanding of social practices. Thus, on this view, to understand corporate ethics we 
have to start from an understanding of what a corporation is. Two points follow immediately.

First, a corporation is an artificial person, not a natural person, and so the ethics of corporations has to be the ethics of artificial persons, not the ethics of natural persons. But moral theory is almost entirely devoted to the ethics of natural persons. Given this, we may doubt the usefulness of applying moral theory to corporations. The point is confirmed if (once again) we take Singer's A Companion to Ethics as a representative sample of the moral theory approach to ethics. The book has nothing to say about corporations or about artificial persons.

Second, as noted above, corporations are much more than artificial persons that engage in business activities. They can have many other purposes. Thus, "business ethics" has to be treated as separate category from "corporate ethics". "Business corporation" is of course a perfectly valid category, but it is a composite concept that needs to be taken apart for analytical clarity. To illustrate, international sporting bodies (world soccer, world cycling, the Olympics) seem to generate ethical scandals on a regular basis, but, while of course money is always involved, the scandals are not primarily scandals of business misconduct. These bodies are corporations but not businesses; they are sporting bodies, whose task is to govern a sport in an ethical manner. Viewed as businesses they may be very successful, while at the same time form a sporting viewpoint, they are overseeing ethical failures.

"Business ethics" is one branch of social ethics sometimes recognised in the moral theory textbooks. Two topics dominate the discussion of business ethics in these textbooks. The first is the problem of the ethics of whistleblowing. The setting for that problem is the internal structure of the corporation (or some other similarly hierarchical structure, such as a government department). The whistleblowing problem has no special reference to business. It arises when the legitimate purposes of the corporation are, apparently, being subverted by a subset of the persons who together make up the artificial person that is the corporation. That subset occupies a place in the corporate role structure, and the structure is itself made up of sets of rights and duties attached to each role. A would-be whistleblower has to work with a knowledge of the role structure not just in order to be 
effective but, more importantly, in order to make just claims and criticisms. It is unclear whether moral theory has anything to contribute to the understanding of the ethics of whistleblowing. In general, moral theory as commonly presented by philosophers avoids talking directly about the rights and duties that go with particular roles, preferring to work at a more general level. But students of social ethics can grasp the issue of whistle-blowing without deriving it from the level of moral theory.

The second ethical issue that has dominated business ethics is that of the social responsibilities of business corporations. Singer's A Companion to Ethics - though largely following a moral theory approach to ethics - contains a chapter on "Business ethics" by Robert C. Solomon that puts forward a social practices approach to the issue of social responsibility. Solomon (writing in 1991) observes that

Only ten years ago, the subject was still an awkward amalgam of a routine review of ethical theories, a few general considerations about the fairness of capitalism, and a number of already-standard business cases - most of them disgraces, scandals and disasters displaying the corporate world at its worst and its most irresponsible.

Business ethics was a topic without credentials in 'mainstream' philosophy, without conceptual subject matter of its own. (p. 354)

He goes on to contend that "Business life is first of all fundamentally co-operative. It is only within the bounds of mutually shared concerns that competition is possible". "Atomistic individualism", he adds, "is naïve in its supposition that no institutional rules and practices underlie even the simplest promise, contract or exchange. Business is a social practice, not an activity of isolated individuals" (Solomon, 1991, p. 358).

The question then arises whether this "social practices" approach to business ethics can be made to work without reliance upon some moral theory. The remainder of Solomon's chapter fails to answer that question. He talks about the social responsibilities of businesses to their "stakeholders", the consumers of their products, and their employees, but with no account of what underpins those responsibilities. At no point does he rely on any of the moral theories that dominate Singer's compendium, but neither does he say how, in general, his approach is supposed to work. "Social responsibility ... is not an additional 
burden on the corporation but part and parcel of its essential concerns, to serve the needs and be fair to not only its investors/owners but those who work for, buy from, sell to, live near or are otherwise affected by the activities that are demanded and rewarded by the free market system" (Solomon, 1991, pp. 360-361). But unless the idea of fairness is explained, general claims like this leave us (that is, mainly students taking courses on business ethics) no further enlightened.

Can moral theory help us here? "Fairness" gets only one mention in the moral theory chapters of Singer's textbook; even "justice" gets only a few mentions in those chapters. There is no one chapter devoted to explaining justice and fairness. (By contrast, in Cicero's On Duties, justice is the primary subject of his Book One and Book Three, making up twothirds of the whole work). A student who, having read Solomon's chapter, turned to the mentions of fairness and justice in those chapters to fill out their understanding of business ethics will get very little guidance.

In the absence of an account of justice or fairness derived from one or other of the various moral theories, we seem driven back to a "social practices" account of corporate social responsibility. What would that be? It can't be merely that "stakeholders" are members of "society" and so corporations have obligations to them: that would be an obvious nonsequitur. And whatever it might be, it would need to take account of the fact that corporations are artificial persons. If we accept that only natural persons can be generous, this rules out the contention that corporations should be generous and corporate social responsibility is a form of generosity.

There is a large philosophical literature about "artificial persons" and related concepts. Risser (n.d.) gives an admirable summary of this work, dating back to the contributions of Peter A. French (see French, 1984; 1995) and Joel Feinberg (1970). There is no need to pursue this topic to a conclusion; the point here is to raise the issue of ethical method. Should issues of corporate ethics be approached from the standpoint of one or another moral theory? Or should we approach them from the standpoint of social practices, which centres on the corporation as a kind of artificial person? My argument is in favour of the latter. Solomon, at least in his contribution to Singer's Companion, also starts from the 
latter, but fails to carry it through. My suggestion is that teachers of corporate ethics should be aware of the question of ethical method.

\section{Public sector ethics}

It is a puzzling fact that ethics textbooks rarely discuss public sector ethics. Puzzling, because government is powerful and pervasive and the largest of employers, and because government employment generates a special set of ethical problems. Neither the moral theory textbooks (Harris, 2007; Singer, 1991) nor the professional ethics textbooks (Martin, Vaught \& Solomon, 2010; Callahan 1988) nor the business ethics textbooks (Bowie, 2002; Frederick, 1999) give any recognition of this. It seems to fall between the usual categories.

In modern societies governments possess, uniquely, both authority and power, authority being a monopoly of collective decision-making and power being a monopoly of violence. Authority and power pervade all of the branches of government, not just the military and the police, but down to the lowest level of the bureaucracy. Whether, for example, an applicant gets a driver's license is decided by a government official. In many matters appeal is possible, but it is appeal from one branch of government, the administrative, to another, the judicial.

If we follow the "social practices" model, the type of ethics applicable to government administration follows immediately from basic facts of this kind. Not all governments are grounded in social cooperation - military dictatorships, ideologically-based systems of dominance, and theocracies may derive authority and power from other sources. But where government is the product of social cooperation, as will be assumed here, the ethics of government seems to be the ethics of one kind of social practice. The alternative is to derive the ethics of government from the catalogue of moral theories put forward by the philosophers. There is an obvious reason why such theories will seem irrelevant to public sector employees working for legitimately-elected governments that follow the rule of law: they already have a primary ethical duty, namely to carry out the laws and regulations relevant to the role within which they are employed. Moral theories may help them to the degree that they have some discretion, but that degree may seem rather small. 
One central concept for the ethics of government is that of "corruption". The concept can of course apply to the legislative and judicial branches of government, but here we are concerned only with the administrative branch, the "public sector", the branch in which government provides employment. Governments, even in their administrative branch, exercise powers of coercion. Coercion may be practiced justly or unjustly. Justice in this context is understood as carrying out the requirements of laws and regulations, and where discretion is possible, acting in the public interest or on the basis of reasons provided in the implementing legislation. But smart operators can often find ways to act under the appearance of these ideals while also obtaining personal benefit or sectional or partisan gains.

To prevent the "corruption" of government, modern liberal democracies require that public servants adopt an ethic of neutrality and impartiality. They must be impartial not just between competing political parties and their ideologies, but between many other social forces: between ethnic groups, between religions and religious denominations, between local and regional allegiances, between rich and poor, between capital and labour, for example. This is a demanding ethical requirement. It is even more so when the requirement of impartiality seems to conflict with one's own sense of justice. Pursuing the latter can result in actions we now describe as "noble cause corruption".

The concept of corruption, particularly of the corruption of institutions, has been explored by Miller (2009, pp. 154-175). His analysis is a valuable one in part because it provides a framework for understanding ethics in the public sector. It offers another version of social ethics as the ethics of social practices. Miller does not discuss Maclntyre's distinction between social practices, which have "internal goods", and social institutions, which serve as the protective structure for social practices. The "internal good" of government is presumably some kind of "justice". Miller (2009, p. 65) comments that, many moral rights, duties, values, principles, and so on are not logically prior to social institutions. Consider in this connection the moral right to vote, the moral right to a fair trial, the right to buy and sell land, and the moral right to a paid job; the first right presupposes institutions of government of a certain kind (democratic 
government), the second criminal justice institutions of a certain kind (e.g., courts of law that adjudicate alleged crimes), and the third and fourth economic institutions of a certain kind.

This is in the spirit of the idea of "social ethics" advocated here.

\section{Ethics in the voluntary sector}

The ethics of the voluntary sector shares with the ethics of government a near-invisibility in the ethics curriculum. It is not easy to find anything of relevance in the ethics textbooks. The question is outside of the scope of the textbooks focused on the professions. The textbooks grounded in the moral theory approach might, but don't, deal with the question. The importance of the topic is clear enough. Students taking "social ethics" need to know more than just the ethics of business, professions and government. They need to be made aware of the "intermediate institutions" that sit in the space that is not individual, family, business or government, which can be designated the voluntary sector or "civil society", and which is in an obvious sense a paradigm of "the social". Voluntary associations are, in large part, pure forms of social cooperation. The difficulty in introducing this sector is to say something general but distinctive about the "ethics" that operates in it.

The diversity of the voluntary sector is its most obvious social dimension. It includes sporting clubs, religious entities, political parties, educational bodies, unions, business associations, charities, voluntary welfare providers, hobby and craft groups, arts societies, advocacy and interest organisations, and much else. Some of these are passionately political, some quite non-political.

The most obvious ethical fact about the voluntary sector is that it is voluntary, in the sense that it is entered freely, but also in the sense that it is entered primarily without thought of financial reward or economic need. Many of the larger "voluntary" organisations do of course employ people, but they do so in large part out of the freely given donations of their supporters. This simple fact is ethically important, though the moral to be drawn from it may be unclear. Perhaps the moral is that voluntary organisations should resist commercial and government subsidisation. 
Maclntyre's account of social practices highlights the intrinsic value of voluntary associations. He takes the example of a chess club as illustrative (Maclntyre, 1985, p. 194). Chess playing is a practice; chess clubs are institutions to protect and support the internal goods that are central to chess playing. Typically, such a club is not motivated by economic necessity or gain; its core motivation is a love of the game and of the goods that the game fosters. It allows various kinds of talent to find expression. The club typically rewards excellence both in the playing of the game and in leadership of the club. Of course, voluntary associations can be riddled with petty power struggles, but these are more easily identified as such than they are in contexts where the aims are more complex and the scale is larger. Conflict is usually face-to-face, between parties known to each other in a variety of ways, so it is difficult to hide behind anonymity.

Some voluntary associations are large, wealthy and powerful. The Catholic Church has a baptised membership of about 1.3 billion people. The world soccer body, FIFA, has revenues of nearly \$US5 billion. They still have their own internal goods, the good of the faith or the good of the game, about which contestation can occur and to some degree reach resolution. The large associations structure themselves as corporations, so the ethics of corporations apply to them just they do to business corporations. They also often have a commercial dimension, selling products to their "followers", so commercial ethics comes into play at that point. And in some cases, their employees are professionals, the priesthood being an example, so in that respect they fall under that branch of ethics.

In the simple case of the local chess club, there are no professionals, and there is no corporate structure and no commercial activity. What then can be said about ethics in that context? One answer is that such simple cases still have internal complexity. They are much more than casual groupings of people coming together out of a common interest. Even when they are not incorporated, voluntary associations operate within a structure. They have a constitution, a set of aims, a management process, authority, minute-keeping, financial reporting, and a general assembly in the Annual General Meeting, at which all members are equals and any can ask questions and stand for office. All this makes them 
miniature polities with quasi-legal processes. Their ethics is in part adherence to the standards implicit in these structures.

In Singer's A Companion to Ethics, there is nothing on the kind of morality relevant to voluntary associations, nor even much on voluntariness, and consent gets little explication. Voluntary associations are consensual communities created for specific purposes. In a chapter on "The Social Contract Tradition" (classified here as a type of moral theory), Will Kymlicka compares classical (natural law), Hobbesian (mutual advantage) and Rawlsian (hypothetical) accounts of social contract, and concludes that "In the end, there is very little that unites the [social contract] tradition as a whole. ... In a sense there is no contract tradition in ethics, only a contract device which many different traditions have used for many different reasons" (1991, p. 196). He interprets the "tradition" as attempting to explain obligations to the state or other large form of association. He doesn't consider the potential use of the social contract tradition in voluntary associations, even though these associations are consensual in ways that the state is not.

The literature on "civil society" is perhaps more helpful. Ehrenberg (1999, p. 233) observes, somewhat sceptically, that in recent times,

... it is civil society that is supposed to revive communities, train effective citizens, build habits of respect and cooperation, provide a moral alternative to self-interest, limit intrusive bureaucracies, and reinvigorate the public sphere - all this in an environment of small government and local politics.

These are large claims that are widely endorsed. Sometimes they are made in praise of the reality of civil society in Western societies (Gellner, 1994, contrasts both Islamic and communist societies); sometimes they are made in a spirit of regret for the supposed loss of civic institutions in Western societies (Putnam, 2000). Their ethical importance is obvious, but their exact ethical status is unclear. Maclntyre, in Dependent Rational Animals (1999: chapter 11 ), is one of the few philosophers to try to give a more precise characterisation, introducing the concept of "just generosity" into the discussion of civil society. To put this in a general form, civil society can be seen as both the expression of and the nurturer of the full range of the virtues, including generosity and gratitude. More recently, Joseph Dunne (2013) offers a friendly criticism of Maclntyre's viewpoint. 
Once again, my purpose is not to state a definite position about these questions, but to contend that the issues here are ones that should be taught in courses on social ethics.

\section{Conclusion}

There are seven claims that I have contended for in this essay. (1) That "social ethics" is a field of ethics, commonly taught at university and college level, that stands between philosophical ethics, also known as "moral theory", and occupational ethics. (2) That social ethics as a field of ethics currently lacks a clear focus, being torn between the two disciplines that stand on either side. (3) That social ethics can be given greater definition by grounding it in "social practices". (4) That five forms of social practice are highly relevant here, since they are central to the world of work that students will soon enter, the five being professions, commerce, corporations, government administration, and the voluntary sector. (5) That these five each have some distinctive ethical features and concepts that cannot be helpfully explicated by "moral theory". (6) That the proper way to explicate the ethics of these five forms of social practice is by starting from the ethical concepts already built into each of these forms. (7) That "social ethics" as a university or college course will benefit if it follows the procedures implied in this analysis.

These are large claims. I don't pretend that my understanding of "social ethics" is the only one possible; others may be better. As mentioned above, social ethics may be conceived more broadly than I have suggested. It may, for example, include the ethics of personal and family life. It may find a place for such standard topics such as abortion and euthanasia. Similarly, social ethics courses may incorporate some elements of "social theory", as expounded by Durkheim, Weber, and their successors. But, on my view, these inclusions will still be grounded in an understanding of social practices, and not be ethics derived from the conventional moral theories. More importantly, moral theories generally fail to provide an account of justice or fairness. The ethics of social practices needs to be complemented by such an account; it is central to ethics today, just as it was for Plato, Aristotle and Cicero. Examples from the literature discussed being here include Ewin (1981, pp. 71-97), MacIntyre (1985, pp. 244-255) and Miller (2009, pp. 81-90). Whatever account of justice or 
fairness is offered, it would need to be one that can show its value in clarifying problems in real social life.

Today, "social ethics" is only a sub-branch of the field of ethics, and its status in the university or college curriculum is very tenuous. I think we can still see it as a remote descendant of the kind of ethics we find in Cicero's On Duties. Of course, no such course today will manage "to pull together, to integrate, and to give meaning and purpose to the student's entire college experience and course of study" (as Sloan put it, as quoted above) - we no longer live in the sort of world presupposed by that proposition. But it might still help to equip students for life in the wider social world of work, government and civil society.

\section{Acknowledgements}

I am grateful to the following for helpful comments and conversations: Hugh Breakey, Diana Davies, Bob Ewin, Geoff Gallop, Bernard Harrison, Andrew Hunter, Dawn Partridge, Marion Tapper and Robin Tapper.

\section{References}

Almond, B. (Ed.). (1995). Introducing applied ethics. Oxford, UK: Blackwell.

Beadle, R. (2002). The misappropriation of Maclntyre. Philosophy of Management, 2(2), 45-54.

Beadle, R. (2008). Why business cannot be a practice. Analyse \& Kritik, 30(1), 229-241.

Beadle, R. \& Moore, G. (2006). Maclntyre on virtue and organization. Organization Studies, $27(3), 323-340$.

Beauchamp, T. L. \& Childress, J. F. (2013). Principles of biomedical ethics ( $7^{\text {th }}$ ed.). New York, NY US: Oxford University Press.

Bowie, N. (Ed.). (2002). The Blackwell guide to business ethics. Oxford UK: Blackwell.

Buchholz, R. A. \& Rosenthal, S. B. (1999). Social responsibility and business ethics. In R. E. Frederick (Ed.), A companion to business ethics (pp. 303-321). Oxford UK: Blackwell. 
Callahan, J. C. (Ed.). (1988). Ethical issues in professional life. New York, NY US: Oxford University Press.

Cicero. (1913). On duties. (W. Miller, Trans.). Cambridge, MA US: Harvard University Press.

Dunne, J. (2013). Ethics at the limits: A reading of Dependent rational animals. In F. O'Rourke (Ed.), What happened in and to moral philosophy in the Twentieth Century? Philosophical essays in honor of Alasdair Maclntyre (pp. 57-82). Notre Dame, IN US: University of Notre Dame Press.

Ehrenberg, J. (1999). Civil society: The critical history of an idea. New York, NY US: New York University Press.

Ewin, R. E. (1981). Cooperation and human values: A study of moral reasoning. New York, NY US: St. Martin's Press.

Ewin, R. E. (1991). The moral status of the corporation. Journal of Business Ethics. 10(10), 749-756.

Ewin, R. E. (1993). Corporate loyalty: Its objects and its grounds. Journal of Business Ethics, 12(5), 387-396.

Ewin, R. E. (1995). The virtues appropriate to business. Business Ethics Quarterly, 5(4), 833842.

Ewin, R. E. (2012). Kovesi's moral point of view. In A. Tapper \& B. Mooney (Eds.), Meaning and morality: Essays on the philosophy of Julius Kovesi (pp. 43-58). Leiden, NL: Brill.

Feinberg, J. (1970). Collective responsibility. In Feinberg, Doing and deserving: Essays In the theory of responsibility (pp. 222-251). Princeton: Princeton University Press.

Frederick, R. E. (Ed.). (1999). A companion to business ethics. Oxford, UK: Blackwell.

French, P. A. (1984). Collective and corporate responsibility. New York, NY US: Columbia University Press.

French, P. A. (1995). Corporate ethics. Fort Worth, TX US: Harcourt Brace College Publishers.

Frey, R. G. \& Wellman, C. H. (Eds.). (2003). A companion to applied ethics. Oxford, UK: Blackwell.

Gellner, E. (1994). Conditions of liberty: Civil society and its rivals. London, UK: Hamish Hamilton.

Gert, B., Culver, C. M., \& Clouser, K. D. (2000). Common morality versus specified principlism: Reply to Richardson. Journal of Medicine and Philosophy, 25, 308-322. 
Hager, P. (2011). Refurbishing Maclntyre's account of practice. Journal of Philosophy of Education, 45(3), 545-561.

Harris, C. E. (2007). Applying moral theories. ( $5^{\text {th }}$ ed.). Belmont, CA US: Cengage.

Harrison, B. (2012). Kovesi's refutation of Hume. In A. Tapper \& B. Mooney (Eds.), Meaning and morality: Essays on the philosophy of Julius Kovesi (pp. 19-42). Leiden, NL: Brill.

Kovesi, J. (1967). Moral notions. London, UK: Routledge Kegan Paul; reprinted (2004), Christchurch, NZ: Cybereditions.

Kymlicka, W. (1991). The social contract tradition. In Singer (Ed.), A companion to ethics (pp. 186-196). Oxford, UK: Blackwell.

Lustig, B. A. (2104). Asymmetrical applications, general norms and specified duties: A commentary on Tapper and Millet's "Is professional ethics grounded in general ethical principles?". Theoretical and Applied Ethics, 3(1), 81-86.

Maclntyre, A. (1967). A short history of ethics. London, UK: Routledge Kegan Paul.

Maclntyre, A. (1985). After virtue: A study in moral theory ( $2^{\text {nd }}$ ed.). London, UK: Duckworth.

Maclntyre, A. (1999). Dependent rational animals: Why human beings need the virtues. Chicago and La Salle, IL US: Open Court.

MacIntyre, A. \& Dunne, J. (2002). Alasdair Macintyre on education: In dialogue with Joseph Dunne. Journal of Philosophy of Education, 36(1), 1-19.

Martin, C., Vaught, W. \& Solomon, R. C. (Eds.). (2010). Ethics across the professions: A reader for professional ethics. New York, NY US: Oxford University Press.

May, W. F. (1975). Code, covenant, contract, or philanthropy. The Hastings Center Report, $5(6), 29-38$.

May, W. (2001). Beleaguered rulers: The public obligation of the professional. Louisville, KY US: Westminster John Knox Press.

Miller, S. (2009). The moral foundations of social institutions: A philosophical study. Cambridge, UK: Cambridge University Press.

Moore, G. (2002). On the implications of the practice-institution distinction: Maclntyre and the application of modern virtue ethics to business. Business Ethics Quarterly, 12(1), 19-32. 
Moore, G. (2017). Virtue at work: Ethics for individuals, managers, and organizations. Oxford, UK: Oxford University Press.

Noddings, N. (2003). Is teaching a practice? Journal of Philosophy of Education, 37(2), 241251.

PhilPapers, Normative ethics. Retrieved from https://philpapers.org/browse/normativeethics. Accessed on April 19, 2020.

PhilPapers, Applied ethics. Retrieved from https://philpapers.org/browse/applied-ethics. Accessed on April 19, 2020.

Putnam, R. (2000). Bowling alone: The collapse and revival of American community. New York, NY US: Simon and Shuster.

Rhodes, R. (2001). Understanding the trusted doctor and constructing a theory of bioethics. Theoretical Medicine, 22, 493-504.

Richardson, H. S. (2000a). Specifying norms as a way to resolve concrete ethical problems. Philosophy and Public Affairs, 19, 279-310.

Richardson, H. S. (2000b). Specifying, balancing, and interpreting bioethical principles. Journal of Medicine and Philosophy, 25, 285-307.

Risser, D. T. (n.d.) Collective moral responsibility. Internet Encyclopedia of Philosophy. Retrieved from https://www.iep.utm.edu/collecti/. Accessed on April 19, 2020.

Sidgwick, H. (1919). Outlines of the history of ethics for English readers ( $4^{\text {th }}$ ed.). London, UK: Macmillan and Co Limited.

Singer, P. (Ed.). (1991). A companion to ethics. Oxford, UK: Blackwell.

Sloan, D. (1980). The teaching of ethics in the American undergraduate curriculum, 18761976. In D. Callahan \& S. Bok (Eds.), Ethics teaching in higher education (pp. 1-57). New York, NY US: Plenum Press.

Solomon, R. C. (1991). Business ethics. In P. Singer (Ed.), A companion to ethics (pp. 354365).

Strong C. (2000). Specified principlism: What is it, and does it really resolve cases better than casuistry? Journal of Medicine and Philosophy, 25, 323-341.

Tapper, A. \& Millett, S. (2014). Is professional ethics grounded in general ethical principles? Theoretical and Applied Ethics, 3(1), 61-80.

Tapper, A. \& Millett, S. (2015). Revisiting the concept of a profession. Research in Ethical Issues in Organisations, 13, 1-18. 